\title{
FDI Equity Inflows in Economic Development in India
}

\author{
S. Chandrasekar, MK. Ganeshan, C. Vethirajan
}

\begin{abstract}
Outside Direct Investment nation's economic background. In nations just as India, Do assets's movements isn't meant by the nation of origin to the host nation yet in addition incorporates the conversational practices associated with the executives, joint endeavors, innovation move, and information, and so on. The present pattern in Foreign Direct Investment aids the upliftment of India with regards to mostly employment buildings and that lifts the amount of fare of the hosting nation. The countries like India are selected to invest because, low-cost labor, huge market size, enormous natural, corporal resources and having young graduates. The Indian government one of the hug initiatives make in India policy, skill India, digitalization, sustainable economic growth, etc. The government of India launched major sector-wise divided into infrastructure, automotive, pharmaceuticals, service, railways, chemicals, textiles, airlines, etc. Huge shareholders have contributed to the Foreign Direct Investment in India, but $80 \%$ of cumulative Foreign Direct Investment Is due to the top ten countries. The remaining inflows $20 \%$ of shared by the rest of the world from 2013 to 2019. However, among these top ten countries, only Mauritius contributed to the lion share of investment in India. This paper focuses to attempt the analysis of Foreign Direct Investment and economic development in India. The researcher has analyzed the different according to various partitions.
\end{abstract}

KEYWORDS: FDI, Management, Capital, Joint Ventures, Technology, Host Country.

\section{INTRODUCTION}

In the year 1991 FDI was presented under the demonstration of Foreign Exchange Management It is a significant wellspring of non-obligation budgetary hotspots for the monetary India's improvement. Remote organizations put resources into India to exploit moderately bring down salary, exceptional speculation benefits, for example, charge exclusions, Free exchange, and so on. For a country where remote endeavors are being built, it also infers achievement of particular capacity and deliverable working. The guideline focusing of this assessment is the methodology through which the FDI addition towards the variant territories in monetary enhancement in India. The Definition of Foreign direct venture is an interest in an organization with the help of a speculator from one nation's organization advantages situated into another nation for which the remote financial specialist has command over the organization bought.

Revised Manuscript Received on December 5, 2019.

* Correspondence Author

Dr.S.Chandrasekar, Assistant Professor, Department of Commerce, Madura College (Autonomous), Madurai - 625011, Tamilnadu, India

MK.Ganeshan, Ph.D Research Scholar, Alagappa Institute of Management, School of Management, Alagappa University, Karaikudi, Tamil Nadu, India.

Dr.C.Vethirajan, Professor \& Head, Department of Corporate Secretaryship, School of Management, Alagappa University, Karaikudi 630 003, Tamil Nadu, India
The Organization of Economic Cooperation and Development characterizes control as owning $10 \%$ or a greater amount of the business associations. The organizational intuition, that brought the outside direct ventures are frequently. A MNE by presenting another remote undertaking would build an immediate speculation that is in term begat as Greenfield venture by the accomplishment either called an acquisition because of the merger or takeover. FDI is a prompt theory by a venture in a business experience in another nation. The contributing society must confine 10 percent or a more prominent measure of the law based limit of the new interest. FDI is that hypothesis, which is making to serve the business interest of the monetary expert in an association, which is a reserved nation locale from the examiner's country of beginning stage. A parent business undertaking and its remote auxiliary are various sides of the FDI relationship. Outside presumption gives a ludicrous move up to the development of the Indian Economy. The tireless inflow of remote direct theories, which is at present permissible over persuaded organizations, shows the declaration outside examiners have in the country's cash related structure.

\section{ADVANTAGES OF FDI}

There are various benefits of Foreign Direct Investments in India given below.

1) Promotion of interest in key territories

2) New technologies

3) Increase in Capital inflow

Exports Increment

Employment openings Advancement

Money related administrations Advancement

Swapping scale solidness

Advancement in reverse regions

Usual characteristic assets

Variation the way of life of individuals

\section{REVIEW OF LITERATURE}

Prior to this study, various studies have been conducted by different researchers. Some of the revisers are given below. Ashoka, Mody(2007), referenced in his investigation that, remote direct speculation and the world economy FDI is thrice honored. It brings share capital where capital required and profitable.

Chaturvedula (2011), in this paper, he dissected the various guide of FDI inflows in India. The paper likewise investigates the area shrewd dispersion of FDI so as to know the overwhelming segment which has pulled in the significant portion of FDI in India. He additionally inspected in his investigation that there is a high level of the relationship amongst FDI and financial expansion.

Gupta (2016) expressed in his investigation that FDI assumes a noteworthy job in the business improvement of the host nation. FDI includes local assets, loads of generation and expanding

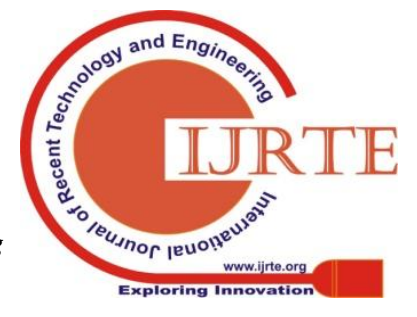


work choices in creating territories which that will prompt the industry expansion of the country.

Rishabh Shroff (2018) clarified the Indian bureau gave its endorsement to the number of important revisions to the FDI arrangement of India. It likewise changes and improves a comparable idea. In this way, the procedure to draw in and required outside money to fuel India enlargement.

\section{Scope of the Study}

As this examination is expected to investigate the pattern in the value stream, the primary spotlight is given on the ongoing patterns in the internal FDI inflows, areas joining the most noteworthy FDI, and the portion of top contributing nations and it covers just do particularization of capital parts. The degree is constrained to the accessibility of auxiliary information.

\section{OBJECTIVES OF THE STUDY}

- To study the FDI and development.

- To analyze the different sector-wise FDI equity inflows in India.

- To examine the FDI equity inflow.

- To check the trends in FDI for the period of a year.

- To offer suggestions for enhancing FDI in India.

\section{RESEARCH METHODOLOGY}

The study has mainly conducted on the basis of secondary data. To clarify certain concepts of the study, secondary data have been gathered from various sources such as reputed journals, newspapers, published records of commercial.

\section{FDI IN INDIA}

Away from the living creatures a fundamental state of money related advancement, Foreign Direct Investment is a significant supporter cause of non-commitment arranging resources . Controlling specialists also put salary into India to do exploitation of modestly bring down remuneration, express endeavor benefits, for instance, charge avoidance, etc. For a country where outside hypotheses are being made, it furthermore infers performing consistent skilled ability and making business. The Indian government's certain methodology rules and a strong business air have ensured that remote capital keeps running into the country. The association has taken bountiful procedures , for instance, loosening up FDI rules

\section{Recent Enhancements:}

India emerged trend as the top recipient of Greenfield FDI Inflows from the Commonwealth, as per a business evaluate modify by The Commonwealth in the year 2018-2019.

Some of the recent noteworthy FDI announcements are as given below:

In October 2019, French oil and gas have secured a 37.4 percent stake in Adani Gas Ltd for Rs 5,662 crore making it the greatest Foreign Direct Investment in India's city gas appropriation territory.

In October 2018, VMware, a main programming enhancing of the US-based industry has reported the venture of US\$ 2 billion in India between 2023.
In August 2019, Reliance Industries pronounced one of India's most noteworthy FDI deals, as Saudi Aramco will buy a 20 percent stake in Reliance's oil-to-engineered substances (OTC) business at an endeavor estimation of US\$ 75 billion

In the year August 2018, Bharti Airtel Limited got the assent of the Government of India accessible to be acquired of a 21 percent stake in its DTH arm to USA based private worth firm to lend $\$ 360$ million.

In the period of June 2018, Idea's interest for fully proportional of FDI was avowed with the help of the Department of Telecommunication trailed by its Indian getting together with Vodafone organization building Vodafone Idea the best telecom manager in India.

In the 5th month of 2018, Walmart increased a 77 percent stake in Flipkart for an idea of US\$ 16 billion.

In the second month of 2018, IKEA proclaimed its courses of action to contribute up to Rs 4,000 crore in the territory of Maharashtra to set up multi-bunch stores and experience centers.

Kathmandu based blend, CG Group is planning to contribute Rs 1,000 crore in India by 2020 in its sustenance and drink business

IFC, the hypothesis arm of the World Bank Group, is proposing to be contributed about US\$ 7 billion after 2020 of each couple of supportable and reasonable force source programs in India.

\section{ROAD AHEAD}

India has gotten one of the most engaging making structures inside the marketing place for in general partners hypothesis for the upcoming 12 month period particularly a year.12 month periodically FDI in-flowing in the nation are relied on to ascend to US\$ 76 billion all through passing with half century The Government of India is huge to accomplish US\$ 100 billion worth of FDI inflows in the going with 2020. The World Bank has referenced that private part premiums in India are predicted to make by 8.8 percent in FY 2018-2019 to be more than private utilization progression of 7.4 percent, and in this manner drive the improvement in India's Gross Domestic Product in FY 2018-2019 according to information concern. Change scale used 1 Indian rupee $=0.0145$ united state dollars since on December 31, 2018. The Foreign Direct Investment in India higher by 2160 united state dollars Million in May of 2019. Remote Direct Investment in India medium 1353.40 united state dollars Million from 1995 until 2019, accomplishing an unrivaled high of 8569 united state dollars Million in the 8th month of 2017 and an information low of - 1336 united state dollars Million in the eleventh month of the year. 
Table.1 :Cumulative FDI Inflow into India during the period 2000-2019

\begin{tabular}{|c|c|c|c|}
\hline $\begin{array}{c}\text { SL. } \\
\text { NO }\end{array}$ & $\begin{array}{c}\text { Particulars } \\
\text { (CUMULATIVE AMOUNT ) }\end{array}$ & $\begin{array}{c}\text { FDI inflows(In Rs. } \\
\text { Crore) }\end{array}$ & $\begin{array}{c}\text { FDI inflows(In } \\
\text { United state Million) }\end{array}$ \\
\hline 1. & FDI INFLOWS(Equity inflow + reinvested earnings \\
other capital) & - & $\begin{array}{c}609,838 \text { united state } \\
\text { dollars }\end{array}$ \\
\hline 2. & FDI EQUITY INFLOWS(exclude, amount remitted ) & $2,378,353$ rupees & $\begin{array}{c}420,021 \text { united state } \\
\text { dollars }\end{array}$ \\
\hline
\end{tabular}

Source: DIPP, Govt of India.

Table.2: FDI Inflows during fourth quarter of financial year 2018-19 (1st month of 2019 to 3rd month of 2019)

\begin{tabular}{|c|c|c|c|}
\hline $\begin{array}{c}\text { SL. } \\
\text { NO }\end{array}$ & $\begin{array}{c}\text { Particulars } \\
\text { (FDI inflows) }\end{array}$ & $\begin{array}{c}\text { Amount of FDI } \\
\text { inflows(In Rs. Crore) }\end{array}$ & $\begin{array}{c}\text { Amount of FDI } \\
\text { inflows(In US\$ } \\
\text { Million) }\end{array}$ \\
\hline 1. & $\begin{array}{c}\text { Indian totally FDI INFLOWS (Equity inflow + } \\
\text { reinvested earnings other capital) }\end{array}$ & - & $\begin{array}{c}17,711 \text { united state } \\
\text { dollars }\end{array}$ \\
\hline 2. & EQUITY & 76,603 rupees & $\begin{array}{c}10,874 \text { united state } \\
\text { dollars }\end{array}$ \\
\hline
\end{tabular}

Source: DIPP, Govt of India.

Table3: FDI inflows in India during the financial year 2018-19

\begin{tabular}{|c|c|c|c|}
\hline \multicolumn{2}{|c|}{ Financial year 2018-2019 (April-March) } & Amount of FDI inflows & Amount of FDI inflows \\
\hline 1. & April, 2018 & (In Rs. Crore) & (In US\$ Million) \\
\hline 2. & May, 2018 & 35,104 & 5,348 \\
\hline 3. & June, 2018 & 30,479 & 2,513 \\
\hline 4. & $7-2018$ & 19,597 & 2,770 \\
\hline 5. & $8-2018$ & 19,025 & 2,508 \\
\hline 6. & $9-2018$ & 17,441 & 4,635 \\
\hline 7. & $10-2018$ & 33,472 & 4,698 \\
\hline 8. & $11-2018$ & 34,595 & 1,739 \\
\hline 9. & $12-2018$ & 12,495 & 4,391 \\
\hline 10. & $1-2018$ & 31,056 & 4,408 \\
\hline 11. & $2-2018$ & 31,181 & 2,865 \\
\hline 12. & $3-2018$ & 20,404 & 3,601 \\
\hline \multicolumn{2}{|c|}{2018 -19(between 4- 2018 to 3-2019) } & 25,019 & 44,366 \\
\hline \multicolumn{2}{|c|}{$2017-18$ (between 4- 2017 to 3- 2018) } & 309,867 & 44,856 \\
\hline
\end{tabular}

Source: Remittance-wise details are provided by RBI from April 2000 onwards only. \# Figures are provisional, subject to reconciliation with RBI, Mumbai.

Table 3 illustrates that Foreign Direct Investment inflows having a duration of 60 minutes between 2018 and 2019 . The outcome shows that there is a gigantic deviation in the model of Foreign Direct Investment inflows. In the positive augmentation in the estimation of Foreign Direct Investment inflows in view of various reasons, for instance, the significant enthusiasm of Indian clients, changed government approach, correspondences workplaces anyway after this period the estimation of Foreign Direct Investment is lessened in previous yearly period. The importance of Foreign Direct Investment is enhanced from the hour of the previous year yet after this estimation of Foreign Direct Investment is lessened in view of the diminishing in the monetary estimation of rupees.
Table 4: Share of top investing countries in FDI equity inflows

\begin{tabular}{|l|l|l|}
\hline Sl. No & Country & $\begin{array}{l}\text { proportional to total inflows in } \\
\text { united states dollar }\end{array}$ \\
\hline 1. & Mauritius & $32 \%$ \\
\hline 2. & Singapore & $20 \%$ \\
\hline 3. & Japan & $7 \%$ \\
\hline 4. & Netherlands & $7 \%$ \\
\hline 5. & U.K & $6 \%$ \\
\hline 6. & U.S.A & $6 \%$ \\
\hline 7. & Germany & $3 \%$ \\
\hline 8. & Cyprus & $2 \%$ \\
\hline 9. & UAE & $2 \%$ \\
\hline 10. & France & $2 \%$ \\
\hline
\end{tabular}




\section{MARKET SIZE}

The Department for Promotion of Industry and Internal Trade, Foreign Direct Investment value inflows remained at united states dollar 44.37 billion, the administration's demonstrating to advance simplicity of working together and entertainment in Foreign Direct Investment guidelines and approach is yielding outcomes in the year 2018-19 in India. The numeric information for 2018-19 shows that the administration's area allured the most elevated Foreign Direct Investment value inflow of united states dollar 9.16 billion, prevailing by Personal Computer machines and projects or applications-united states dollar 6.42 billion, exchanging - united states dollar 4.46 billion and data change advances US\$ 2.67 billion. As per late of information, all-out FDI value inflows for the period of March 2019 contacted united states dollar 3.60 billion. All through 2018-19, the Indian organization perceived the greatest Foreign Direct Investmentvalue inflows from Singapore (united states dollar 16.23 billion), which is prevailing by Mauritius (united states dollar 8.08 billion), Netherlands (united states dollar3.87 billion), United State of America (united states dollar3.14 billion), and Japan (united states dollar 2.97 billion).

Table 5 :Vital statistics of sector-wise FDI Equity Inflows:

\begin{tabular}{|c|c|c|}
\hline Count & Various Segments & Proportional inflows(United state dollars) \\
\hline 1. & Servicing Segment & $9 \%$ \\
\hline 2. & CSE s/w and h/w & $9 \%$ \\
\hline 3. & Telecom association & $7 \%$ \\
\hline 4. & Building Enhancement: & $6 \%$ \\
\hline 5. & House facility-Projects of building enhancements & $6 \%$ \\
\hline 6. & Trade sector & $5 \%$ \\
\hline 7. & Automobiling Organization & $5 \%$ \\
\hline 8. & Chemical Industry & $4 \%$ \\
\hline 9. & Pharmacy Sector & $3 \%$ \\
\hline 10. & Construction(Infrastructure) Activities & \\
\hline
\end{tabular}

Source: DIPP, Govt of India.

\section{SUMMARY OF FINDINGS}

For creating nations as a union, the coefficient of debasement, sends out per capita, high development of population, work competence in the benchmarking model are compensation and implication. Consistently, debasement as an optimism hand for capital venture on the wheels of industry just as the Indian economy.

\section{SUGGESTIONS}

The time span picked is additionally confined on the grounds that the information on the debasement gave by straightforwardness global is restricted. This model takes into account the distinction in debasement level among India and host nations which could be an area advantage. The focal point of the investigation is subsequently from an individual or microeconomic viewpoint.

\section{v. CONCLUSION}

The examination of Foreign Direct Investment causes that India ought to welcome Foreign Direct Investment similar it possess the enormous points of interest for the Indianeconomy. Foreign Direct Investment shares consistently conveying flourishing to any-rising country. Various preferences that Indian draws by movement .Foreign Direct Investment are making use of pattern setting advancement, aptitude motivating brand quality, enhancing the forcefulness better remoting associations boosting conveying, and showing Indian along with an overall stage. Membership for warrants and the most settled up shares gave by organizations under the programmed course, through FIPB. Simple and quick scope for interest in different parts. Membership of offers consequently of

apparatus traded and imported to organizations. Be that as it may, the Indian government ought to change horticulture, protection, and the media part as it will be useful for the economy to contend comprehensively and have its very own remain in the worldwide market.

\section{ACKNOWLEDGEMENT}

The Co-Author Dr.C.Vethirajan, Professor and Head, Department of Corporate Secretaryship, School of Management, Alagappa University, Karaikudi has greatly acknowledged under RUSA Phase 2.0 Scheme and the Corresponding Author and also Author has acknowledged the same.

\section{REFERENCES}

1. Manisha Dave (2019), "Make in India and its impact on FDI and Indian Economy: A Study", Journal of Modern Management \& Entrepreneurship (JMME) Vol. 08, No. 04, October 2018, pp 239. 244.

2. Priyanka Sabharwal, Sanchit Sabharwal (2019), "An Analysis of Sectoral Trend and Pattern of FDI in India", Journal of Modern Management \& Entrepreneurship (JMME), Vol. 09, No. 2, April 2019, pp 47-54.

3. Harinder (2018), “ An analysis on sectors attracting highest FDI equity inflows in India in current scenario", Journal Advances and Scholarly Research in Allied Education(JASRAE), Vol. 14(2), pp 300-304(5).

4. Pasupathi S, Sakthi V (2019), “ Recent trends of foreign direct investment in India and its impact on economic growth, Journal of Business and Management (IOSR-JBM),e-ISSN-2278-487,p-ISSN 2319-7668, pp.08-11

5. Shikha Singh (2019), "Foreign direct investment inflows in India", Journal of general management research, ISSN 2348-2869, Vol. 6, issue 1, pp.41-53. 
6. Sandeep Kumar, Sheenu Sharma (2017), "Inflow of FDI in the Indian economy: A descriptive analysis", Indian Journal of Science Research, ISSN 0976-2876, Vol. 13(1), pp. 268-272.

7. Bhavya Malhotra (2014), "Foreign Direct Investment: Impact in Indian Economy", Global Journal of Business Management and Information Technology, ISSN 2278-3679, Vol. 4(1), pp 17-23.

8. https://www.coursehero.com/file/p62kqg3/Cumulative-equityforeign-direct-investment-FDI-inflows-in-India-increased-40/

9. www.bulletin.rbi.org.in

10. www.ceicdata.com

11. www.tradingeconomics.com

12. www.ibef.org

13. www.dipp.nic.in

14. www.economywatch.com

15. www.makeinindia.com

16. www.google.co.in

17. www.wikipedia.org

\section{AUTHORS PROFILE}

Dr.S.Chandrasekar is Assistant Professor in the Department of Commerce, Madura College (Autonomous), Madurai, Tamilnadu.He did $\mathrm{Ph} . \mathrm{D}$ under the Guidance of Prof.C.Vethirajan,Professor and Head, Department of Corporate Secretaryship, School of Management, Alagappa University, Karaikudi, Tamil Nadu.

Mr.MK.Ganeshan is a full time Ph.D., Research Scholar in the Alagappa Institute of Management, School of Management, Alagappa University, Karaikudi, Tamil Nadu. He is doing Ph.D., under the Guidance of Prof.C.Vethirajan.

Prof.(Dr.) C.Vethirajan is Professor and Head in the Department of Corporate Secretaryship, School of Management, Alagappa University, Karaikudi, Tamil Nadu. He has received UGC Research Award (20142016). He has 24 years of standing in his academic career. He has published papers in International journals of repute and he is also serving as a reviewer of International journals. 